\title{
Mineral Phosphate Solubilizing Bacteria Isolated from Various Plant Rhizosphere under Different Aluminum Content
}

\section{Dolly Iriani Damarjaya ${ }^{1 *}$, Jaka Widada ${ }^{1}, K$ Keishi Senoo ${ }^{2}$, Masaya Nishiyama ${ }^{2}$ and Shigeto Otsuka}

1. Laboratory of Soil and Environmental Microbiology, Department of Agriculture Microbiology, Faculty of Agriculture, University of Gadjah Mada, Bulaksumur, Yogyakarta 55281, Indonesia.

2. Graduate School of Agricultural and Life Sciences, The University of Tokyo. 1-1-1 Yayoi, Bunkyo-ku, Tokyo 113-8657, Japan.

\begin{abstract}
The objectives of this study was to isolate and characterize the mineral phosphate solubilizing bacteria from rhizosphere and evaluate their potential as plant growth promoting bacteria in Al-toxic soils. The halo zone formation method was used to isolate PSB using the media containing insoluble phosphates (Ca-P or Al-P) as a source of phosphate. Eight of acid and Al-tolerant PSB isolates that were able to solubilize Ca-P were obtained from rhizosphere of clover, wheat, corn, and sunflower grown in Al-toxic soil. Identification of the isolates based on the 16S rRNA gene sequence analysis demonstrated that the isolates were strains of Burkholderia (5 strains), Pseudomonas (1 strain), Ralstonia (1 strain), and unidentified bacterium (1 strains). All PSB isolates showed the capability to dissolve Ca-P, and only 1 strain (Ralstonia strain) was able to dissolve Al-P in agar plate medium. The P-solubilization by these isolates was correlated with $\mathrm{pH}$ of medium. Inoculation of the bacterial strains on clover on Al-toxic medium showed that all isolates increased the plant dry weight compared with uninoculated treatment. Our results showed that those PSB isolates have potential to be developed as a biofertilizer to increase the efficiency of P-inorganic fertilizer used in Al-toxic soils.
\end{abstract}

\section{Introduction}

Aluminium (Al) toxicity is a primary factor limiting the growth and yield of the majority of plants grown in mineral acid soils. Numerous studies have demonstrated the marked depressive effects of soluble $\mathrm{Al}$ on water and nutrient uptake root and shoot growth and mineral content in different plant species.

Plant roots provide such suitable habitats for the growth of microorganisms that high numbers of many different microbial populations are found on and in the immediate vicinity of the roots. This

*Corresponding author: Dolly Iriani Damarjaya, Laboratory od Soil and nvironmental Microbiology, Department of agriculture Microbiology, Faculty of Agriculture, University of Gadjah Mada, Bulaksumur, Yogyakarta 55281, Indonesia Tel. +62-274-523065, Fax. +62-274-523062, E-mail: dollyiriani@lycos.com habitat, the rhizosphere, is defined as the region of soil directly affected by the influence or action of a root (Lynch, 1994).

The rhizosphere develops around each root as it grows, changing the chemical and physical properties of the surrounding soil. Thus, $\mathrm{pH}$ in the rhizosphere is usually different from that in the root-free soil, depending on the cation: anion uptake ratio of the roots (Brimecombe et al., 2001), and the redox potential is lower than in root-free soil due to high oxygen consumption by roots and microbes (Darrah and Roose, 2001). The environmental soil conditions in turn have an influence on the composition and amount of root exudates. This rhizodeposition includes lysates, liberated through autolysis of sloughed-off cells and tissues, as well as diffused and/or actively secreted root exudates (Neumann and 
Römheld, 2001). The amount of root exudates produced is proportional to the amount of gross photosynthesis and crop dry matter production. Thus, $1-25 \%$ of net photosynthesis is assumed to be released into the soil (Kraffczyk et al., 1984; Haider et al., 1985; Haller and Stolp, 1985).

The number of soil organisms found in the soil is usually much higher in the rhizosphere than in the root-free soil (Curl and Truelove, 1986; Kennedy, 1999). Different rhizosphere bacteria will probably occupy different niches within the rhizosphere depending on e.g. their utilization of root exudates, growth rate and metabolic production (Lynch, 1994). In the rhizosphere, the composition of the bacterial community have been shown to be regulated by the stage of plant growth (Picard et al., 2000) and the amount of young and old roots (Liljeroth et al., 1991; Duineveld and van Veen, 1999) due to differences in exudates composition.

A number of phosphate solubilizing bacteria (PSB) are known to be present in rhizosphere. They have ability to excrete organic acid that form chelates with $\mathrm{Al}^{3+}$, $\mathrm{Fe}^{3+}, \mathrm{Ca}^{2+}$, and $\mathrm{Mg}^{2+}$ ions and release phosphate previously fixed by these ions. It is desirable if rhizospheric PSB with Al-P solubilizing ability are obtained. Seed or soil inoculation with mineral PSB is known to improve solubilization of fixed soil phosphorus and applied phosphates, resulting in higher crop yields. However, most of the studies on PSB focused on solubilization of calcium phosphate (Ca-P), which appears in alkaline soils. By contrast, very limited studies are available on aluminum-phosphate (Al-P) solubilizing bacteria, which must be important in Altoxic soils.

In this study, isolation of PSB from rhizosphere soil of various plants grown in $\mathrm{Al}$ acidic soil, and evaluation of their Ca-P and Al-P solubilizing ability under acidic condition were carried out. As basic information, effect of $\mathrm{Al}$ on the number of soil microorganisms including PSB in the rhizosphere of various plants was also evaluated.

\section{Materials and Methods \\ Soil and pot experiments}

The subsoil of an Andisols, Japan, was used for making artificial Al-toxic soil due to its properties common to Al-toxic soil such as low organic matter content, low buffering capacity, low available $\mathrm{P}$, and high exchangeable Al. Soil was sieved $(2 \mathrm{~mm})$, amended with $\mathrm{Al}_{2}\left(\mathrm{SO}_{4}\right)_{3}(0,0.4,0.6,0.75 \%$, $\mathrm{w} / \mathrm{w})$, mixed well, and incubated for 1 month with field water capacity at room temperature. Four plant species that relatively tolerant to the $\mathrm{Al}$ toxicity (soybean, corn, rice cultivar Nihon Bare, sunflower) were treated with $0 \%, 0.4 \%$, and $0.75 \%$ $\mathrm{Al}_{2}\left(\mathrm{SO}_{4}\right)_{3}$, while three plant species relatively sensitive to the Al toxicity (clover, wheat, Sesbania rostrata) were treated with $0 \%$ and $0.6 \% \mathrm{Al}_{2}\left(\mathrm{SO}_{4}\right)_{3}$ (data not shown). Seeds were surface sterilized with $70 \%(\mathrm{v} / \mathrm{v})$ ethanol for $5 \mathrm{~min}$ and $6 \% \mathrm{NaClO}$ for 15 min, and washed several times with sterile distilled water, then germinated for one day in sterile filter paper. Three seedlings each were transferred and grown in 200-ml nonsterilized soils amended with basal fertilizer (50 mg kg-1 N-urea; $50 \mathrm{mg} \mathrm{kg}^{-1} \mathrm{~K}-\mathrm{KCl}, 20$ $\mathrm{mg} \mathrm{kg}{ }^{-1} \mathrm{P}-\mathrm{CaP}$, and $0.5 \mathrm{mg} \mathrm{kg}^{-1} \mathrm{Mo-}$ $\mathrm{NH}_{4} \mathrm{MoO}_{4}$ ) just before transplanting. Plants were grown for 2 months in growth chamber with $16 \mathrm{~h}$ light and $8 \mathrm{~h}$ dark at $25^{\circ} \mathrm{C}$. After harvested, the total dry weight of each plant was determined. The rhizosphere soils were sampled as described below for enumeration of PSB (on Ca-P Pikovskaya agar plate), total bacteria (on nutrient agar plate added with $100 \mu \mathrm{g} \mathrm{ml}^{-}$ ${ }^{1}$ cycloheximide), and total fungi (on potato dextrose agar plate, Difco Laboratories, Detroit, MI, USA), and isolation of PSB. 
Isolation of PSB from rhizosphere soil and genotypic characterization

The bacteria were initially isolated from the rhizosphere of the plant. The roots of 2month-old plant were removed from the soils and the 1 gram of fresh root was carefully added to $200 \mathrm{ml}$ Erlenmeyer flask containing $50 \mathrm{ml} \mathrm{Ca-P} \mathrm{Pikovskaya} \mathrm{medium}$ (Pikovskaya, 1948). Serial dilutions were poured on solid (15 $\mathrm{g} \mathrm{l}^{-1}$ agar) Ca-P Pikovskaya medium. Colonies with different morphology and producing a halo zone as a result of Ca-P solubilization were purified on nutrient agar medium and stored in a slant agar of Picovskaya medium at $4^{\circ} \mathrm{C}$. The isolates that have a high ratio halo zone/colony diameter $(\geq 1.2)$ were selected for further experiments.

\section{Amplified rDNA restriction analysis (ARDRA)}

The 16S rRNA gene was amplified from each strain by using the forward primer 27f (5'-AGAGTTTGATC[A/ C]TGGCTCAG-3') which corresponds to the positions 8-27 of the E. coli 16S rRNA and the reverse primer 1492r (5'TACGG[A/T/C]TACCTTGTTA CGACTT$\left.3^{\prime}\right)$ which corresponds to the positions 14921513 of the E. coli $16 S$ rRNA sequence. Genomic DNAs of $P$. putida strains were prepared using cetyltrimethylammonium bromide for precipitation of proteins, exopolysaccharides, and cell debris (Ausubel et al., 1987). Total DNA of each strain was used as a template in PCR, and the reaction condition were those described by HedlundBrian et al. (1999). PCR products were then digested with the restriction endonucleases, HaeIII and HhaI, and resultant restriction fragments were analyzed by electrophoresis on $2.5 \%$ agarose gels.

\section{Repetitive DNA PCR fingerprinting}

One hundred nano grams of genomic DNA from each isolate was used as a template for PCR reaction with the primer
BOXA1R (5'-CTACGGCAAGGCGACG CTGACG-3'). The PCR reaction and amplification were performed as described previously (De Bruijn, 1992; Versalovic et al., 1994). After PCR amplification, PCR reaction mixture was separated by $1.5 \%$ agarose gel electrophoresis using Tris-Acetate-EDTA and stained with ethidium bromide.

Phosphate solubilization by PSB isolates at various $\mathrm{Al}$ concentration and $\mathrm{pH}$

The ability of isolates to solubilize aluminum-phosphate (Al-P) was evaluated in Al-P Pikovskaya agar medium with $\mathrm{AlPO}_{4}$ $\left(4 \mathrm{~g} \mathrm{l}^{-1}\right)$ as phosphate source. The $\mathrm{AlCl}_{3}$ was added to the medium with concentration as follows: $100 \mu \mathrm{M}, 250 \mu \mathrm{M}$, and $1000 \mu \mathrm{M}$. Because addition of $\mathrm{AlCl}_{3}$ decreases $\mathrm{pH}$ of the medium, $\mathrm{pH}$ of the control $\left(\mathrm{no} \mathrm{AlCl}_{3}\right.$ ) was adjusted at 5.5 by adding $\mathrm{HCl}$. The adjustment of $\mathrm{pH}$ and addition of $\mathrm{AlCl}_{3}$ were carried out after autoclaving the medium. The phosphate solubilization activity was determined by calculating the ratio of halo zone to colony diameter after 5 days of incubation.

\section{DNA sequencing and sequence analysis}

The 16S rRNA genes were sequenced by the chain termination method using a LI-COR Model 4200L-2 auto-DNA sequencer (LI-COR Inc., Lincoln, Neb. USA) according to the manufacturer's instruction. The obtained nucleotide sequences were analyzed with DNASISMac software (version 3.7; Hitachi Software Engineering Co. Ltd., Yokohama, Japan). The BASTN method (Altschul et al., 1997) was used for homology searching.

\section{Inoculation of PSB isolates on plant growth under Al-acidic condition}

The inoculation effects of PSB isolates on plant growth were evaluated using clover. The clover was germinated in sterile filter paper and transplanted to the acid and low phosphate artificial medium 
containing vermiculite. The medium was amended with basal nutrient $\left(\mathrm{g} \mathrm{l}^{-1}\right)$ : $\mathrm{NH}_{4} \mathrm{NO}_{3}$ 0.1617; $\mathrm{K}_{2} \mathrm{SO}_{4} 0.176 ; \mathrm{CaCl}_{2} 0.1$; $\mathrm{MgSO}_{4}$ 0.062; Fe-EDTA 0.005; $\mathrm{MnSO}_{4}$ $0.0015 ; \mathrm{H}_{3} \mathrm{BO}_{3} 0.0014 ; \mathrm{ZnSO}_{4} 0.00028$; $\mathrm{CuSO}_{4}$ 0.00025; $\mathrm{NH}_{4} \mathrm{MoO}_{4}$ 0.000124; and $\mathrm{AlPO}_{4}$ 0.271). The medium was irrigated to field capacity with nutrient solution containing $100 \mu \mathrm{M} \mathrm{AlCl}{ }_{3}(\mathrm{pH} 4.8)$ before transplanting, and continued every second day during the growing period. The germinated seed was inoculated with $50 \mu \mathrm{l}$ of 3 day-old bacterial suspension cultured in Ca-P Pikovskaya medium at a cell

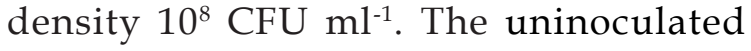
treatment was served as control. The plant was cultivated in culture chamber at $25^{\circ} \mathrm{C}$, light $16 \mathrm{~h} /$ dark $8 \mathrm{~h}$. Thirty days after planting, the plant was harvested then total dry weight was determined. The data are means of three replications.

\section{Results and Discussion}

Effect of different Al content in soil on total soil microorganisms and PSB

The addition of $\mathrm{AlCl}_{3}$ at $0.4 \%$ in all plant, improved the total number of bacteria and PSB. However, generally, the addition of $\mathrm{AlCl}_{3}$ at $0.75 \%$ improved the total number of fungi (Figure 1). The number of soil microorganisms (total bacteria, and total fungi) and number of PSB were influenced by the plant cultivation. In planted soils, the number of microorganisms was higher than in nonplanted soils. These results suggested that the plant promoted the population of rhizosphere microorganisms.
(A)

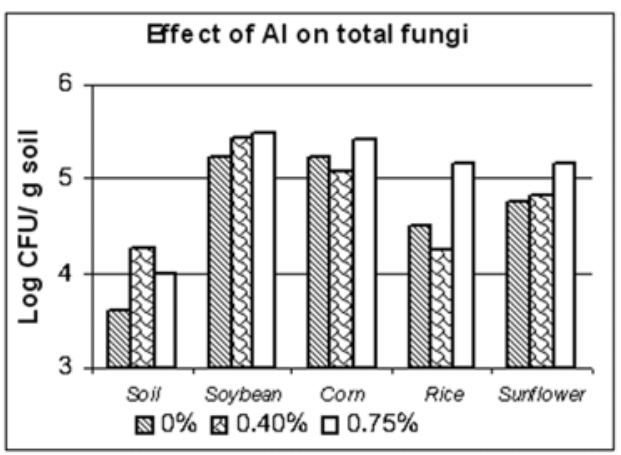

(C)

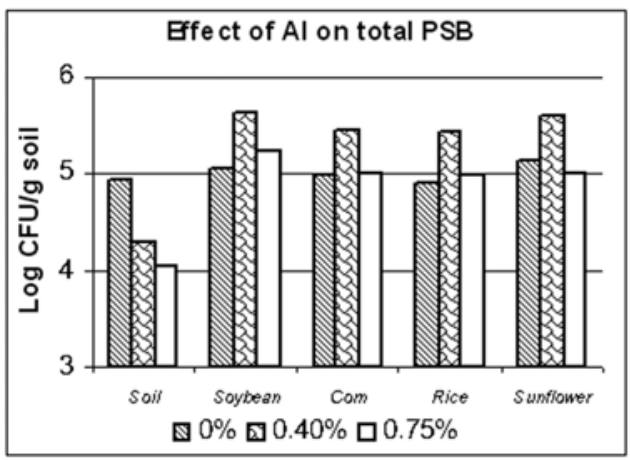

(B)

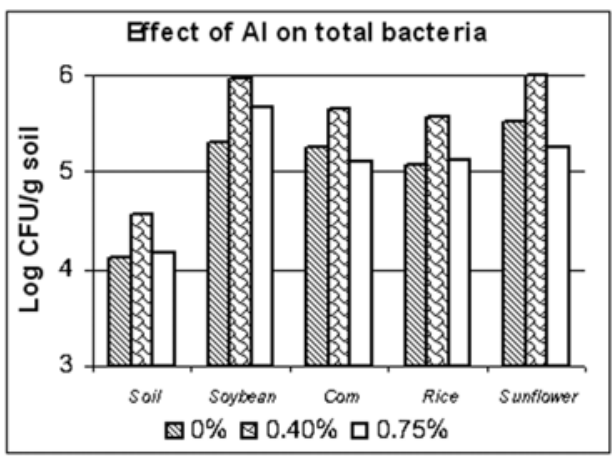

(D)

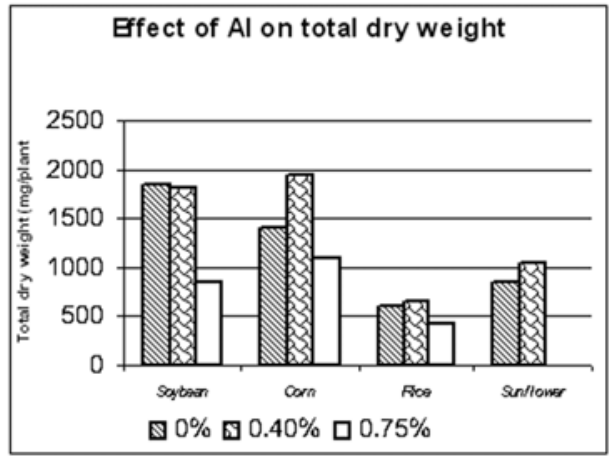

Figure 1. The effect of Al level 0, $0.4 \%$, and $0.75 \%$ on total fungi (A), total bacteria (B), total PSB (C), and total dry weight of plant (D) 
(A)

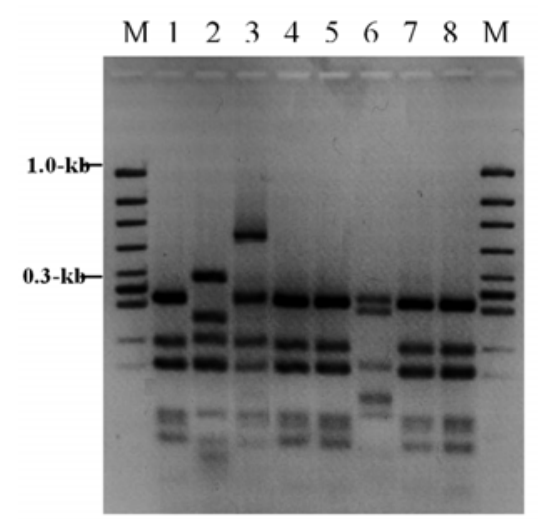

(B)

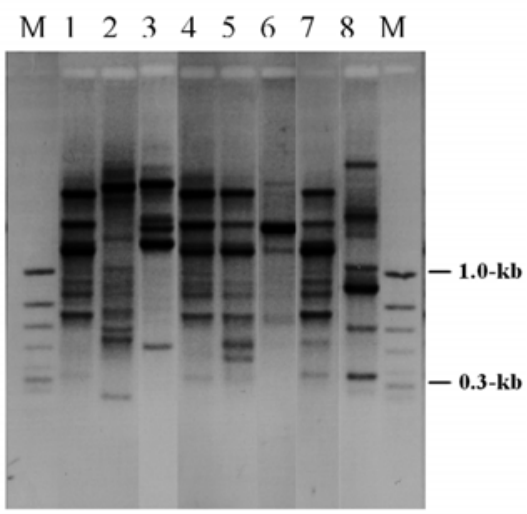

Figure 2. ARDRA profile digested with HhaI and HaeIII restriction enzymes (A) and REP-PCR profile (B) of PSB isolates obtained from rhizospheric mineral acid soils. Lane M: Marker DNA; lane 2-8 were Cl3.6; W1.6; Co.4m; Cl1.0; SF1.6; Co3.0; and Bio respectively.

\section{Isolation and characterization of PSB}

Eight bacterial strains able to solubilize Ca-P were isolated from different plant rhizosphere. The genotypic analysis revealed 4 groups discriminated by ARDRA were obtained in this study (Figure 2A). Identification of bacterial isolates by using $16 \mathrm{~S}$ rRNA gene sequence analysis showed that the isolates belong to Burkholderia (5 strains), Pseudomonas (1 strain), Ralstonia (1 strain), and unidentified bacterium (1 strain) (Table 1). By using REP-PCR analysis, 7 different bacterial groups could be recognized (Figure 2B).

Table 1. PSB bacteria isolated from rhizosphere subsoil of an Andisol

\begin{tabular}{|c|c|c|c|c|c|c|}
\hline \multirow[t]{2}{*}{ Strain } & \multirow{2}{*}{ Origin } & \multirow{2}{*}{$\begin{array}{c}\text { Plant } \\
\text { added } \\
(\mathrm{g} / \mathrm{kg})\end{array}$} & \multirow{2}{*}{$\begin{array}{c}\mathrm{AlCl}_{3} \\
\text { after } \\
\text { harvesting }\end{array}$} & \multirow{2}{*}{$\begin{array}{l}\text { Soil pH Gram } \\
\text { reaction }\end{array}$} & \multicolumn{2}{|c|}{ 16S rRNA gene sequence ${ }^{a}$} \\
\hline & & & & & Best match & Identity \\
\hline $\mathrm{Cl} 3.6$ & Clover & 6 & 4.1 & Negative & Burkholderia sp. & $98 \%$ \\
\hline W1.6 & Wheat & 6 & 4.2 & Negative & Burkholderia sp. & $99 \%$ \\
\hline Co.4m & Corn & 4 & 4.3 & Negative & Unidentified bacterium & - \\
\hline Co.4h & Corn & 4 & 4.3 & Negative & Burkholderia sp. & $97 \%$ \\
\hline $\mathrm{Cl1} .0$ & Clover & 0 & 5.5 & Negative & B. cepacia & $100 \%$ \\
\hline SF1.6 & Sunflower & 0 & 5.9 & Negative & Pseudomonas sp. & $99 \%$ \\
\hline Co3.0 & Corn & 0 & 5.8 & Negative & Burkholderia sp. & $98 \%$ \\
\hline Bio & Corn & 4 & 4.3 & Negative & Ralstonia thomasii & $99 \%$ \\
\hline
\end{tabular}

${ }^{a}$ The partial of 16S rRNA gene were amplified by PCR using universal primer. The PCR products were sequenced and compared with GeneBank Database 
The effect of $\mathrm{Al}$ concentration and $\mathrm{pH}$ on Al-P and Ca-P solubilization of PSB isolates

In the Ca-P solubilizing assay in agar plate medium all PSB isolates formed the halo zone surrounding colony. However, at $\mathrm{pH} 7$, only strain Bio produced the halo zone when Al-P was used as a phosphate source. This finding indicated that only strain Bio has an ability to dissolve Al-P. The ability of PSB isolates to solubilize Al-P also was examined under different $\mathrm{pH}$ and $\mathrm{Al}$ concentration (Table 2). As shown in Table 2, the halo zone formation on Al-P in strains C13.6, C0.4m, C11.0, Co.3.0, and Bio was induced by addition with $250 \mathrm{mM} \mathrm{AlCl}_{3}$ at $\mathrm{pH} 4.5$, while the halo zone formation in strains C13.6, C0.4m, C11.0, Co.3.0 was also induce by decreasing $\mathrm{pH}$ at 4.1 without the addition of $\mathrm{AlCl}_{3}$.

Table 2. The ratio of halo zone/colony diameter formation by PSB isolates at various phosphate source, $\mathrm{pH}$, and aluminum concentration, after 14 days incubation at $25^{\circ} \mathrm{C}$

\begin{tabular}{lcccccccc}
\hline Strain & Ca-P & \multicolumn{7}{c}{ Al-P added with Al (mM) } \\
\cline { 3 - 9 } & & 0 & 0 & 100 & 0 & 250 & 0 & 1000 \\
\hline & pH 7.0 & pH 7.0 & pH 5.5 & pH 4.5 & pH 4.1 \\
\hline Cl3.6 & 1.20 & 1.00 & 1.00 & 1.00 & 1.18 & 1.20 & 1.10 & $\mathrm{ng}$ \\
\hline W1.6 & 1.75 & 1.00 & 1.00 & 1.00 & 1.00 & 1.00 & 1.00 & $\mathrm{ng}$ \\
\hline Co.4m & 1.44 & 1.00 & 1.00 & 1.00 & 1.22 & 1.24 & 1.13 & $\mathrm{ng}$ \\
\hline Co.4h & 1.65 & 1.00 & 1.00 & 1.00 & 1.00 & 1.00 & 1.00 & $\mathrm{ng}$ \\
\hline Cl1.0 & 1.43 & 1.00 & 1.00 & 1.00 & 1.20 & 1.25 & 1.10 & $\mathrm{ng}$ \\
\hline SF1.6 & 1.10 & 1.00 & 1.00 & 1.00 & 1.00 & 1.00 & 1.00 & $\mathrm{ng}$ \\
\hline C03.0 & 1.53 & 1.00 & 1.00 & 1.00 & 1.20 & 1.25 & 1.10 & $\mathrm{ng}$ \\
\hline Bio & 1.07 & 1.10 & 1.36 & 1.27 & 1.40 & 2.33 & 1.00 & $\mathrm{ng}$ \\
\hline
\end{tabular}

ng: no growth

\section{Inoculation effects of PSB isolates on plant growth}

Inoculation of PSB isolates on clover with Al-P as a phosphate source showed that all isolates improved the total dry weight of clover (Figure 3). These results indicated that PSB isolates obtained in this study have a potential as plant growth promoting rhizobacteria in aluminum toxic soils.

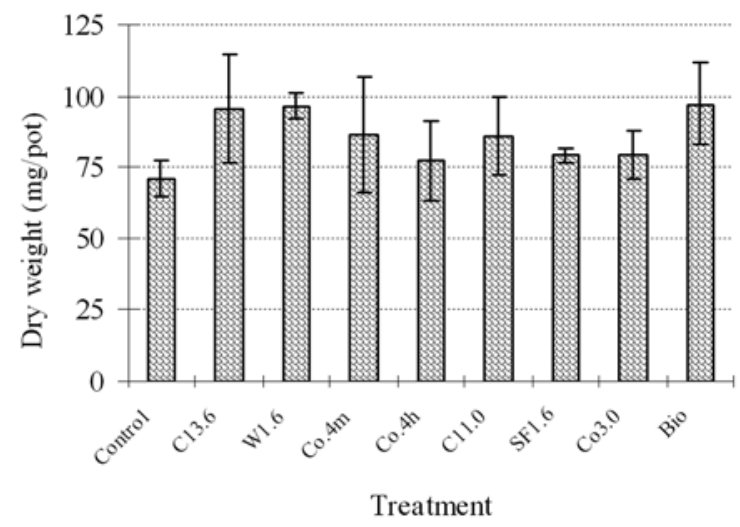

Figure 3. The inoculation effect of PSB isolated from rhizosphere acid soils on dry weight of clover.

The rhizosphere is an ecological niche, which is mainly a black box. Hardly anything is known about the availability of nutrients (organic or inorganic), the dangers, which affect the survival of microorganism (e.g. predation, harmful compounds) or interaction among the rhizosphere organisms (De Weger et al., 1995).

In this study, the population of microorganisms in rhizosphere soil was more influenced by aluminum concentration than by the kind of host plant. Surprisingly, in some case, the addition of $\mathrm{AlCl}_{3}$ on subsoil of an Andisol improved the total microorganisms and plant growth used in this study. Moreover, in addition of $\mathrm{AlCl}_{3}$ at $0.6 \%$ or $0.7 \%$, the population of fungi in some case is still high. The high population of soil fungi in $\mathrm{Al}$ toxic condition may be caused by tolerance of the soil fungi to acidic and Al toxic condition (Alexander, 1977). Relatively little research has been reported about aluminum effects on microorganisms, compared to the plant research. The complex chemistry of $\mathrm{Al}$, which polymerizes, interacts with phosphates and organic acids, and acidifies culture media, frequently complicates the interpretation of 
experimental results (Piña and Cervantes, 1996).

The PSB isolates were obtained from rhizosphere of corn (4 strains), clover (2 strains), wheat (1 strain), and sunflower (1 strain), and most of them belong to genus Burkholderia. Previously, it has been reported that genus Burkholderia is a common plant associate bacteria (Balandreau et al., 2001). Several strains of this genus have also been reported as nitrogen fixer rhizobacteria (Estrada-de los Santos et al., 2001), phosphatase producing bacteria (Rodriguez et al., 2000), and plant growth promoting rhizobacteria (Peix, 2001).

Unfortunately, the Al-P solubilization ability and the Al tolerance of PSB isolates on agar plate medium were quite low. Much more strategies are needed in order to isolate the bacteria that have strong abilities of the Al-P solubilization and the Al tolerance from rhizosphere.

Most of PSB isolates improved the plant growth of clover under acidic and low available phosphate conditions. However, these isolates are poor in Al-P solubilizing ability except strain Bio. Other mechanism than phosphate solubilization, which promote the plant growth will be present in seven PSB isolates, but it is unclear at present. Anyhow, screening of Al-P solubilizing strains under Al acidic condition is necessary.

This result shows that PSB isolates obtained in this study has a potential as plant growth promoting rhizobacteria in aluminum toxic soils. However, the inoculation effect of these isolates on plant growth promotion needs to be further evaluated under different crop and agroclimatic conditions, particularly in the real aluminum toxic soils.

\section{References}

Alexander, M., 1977. Introduction to soil microbiology. New York: John Wiley and Sons. p.467.
Altschul, S.F., Madden, T.L., Schäffer, A.A., Zhang, J., Zhang, Z., Miller, W., and Lipman, D.J., 1997. Gapped BLAST and PSI-BLAST: a new generation of protein database search programs. Nucleic Acids Res., 25, 3389-3402.

Ausubel, F.M., Brent, R., Kingston, R.E., Moore, D.D., Seidman, J.G., Smith, J.A., and Struhl, K., 1987. Current protocols in molecular biology. New Yotk: John Wiley and Sons.

Balandreau, J., Viallard, V., Cournoyer, B., Coenye, T., Laevens, S., and Vandamme, P., 2001. Burkholderia cepacia genomovar III is a common plant-associated bacterium. Appl. Environ. Microbiol., 67 (2), 982-985.

Brimecombe, M.J., De Leij, F.A.A.M., and Lynch, J.M., 2001. The effect of root exudates on rhizosphere microbial populations. In R. Pinton, Z. Varanini and P. Nannipieri (eds.) The Rhizosphere. Dekker, New York, pp. 95-140.

Curl, E.A. and Truelove, B., 1986. The rhizosphere. Advanced Series in Agricultural Sciences. Berlin, New York: Springer-Verlag, pp. 15:288.

Darrah, P.R. and Roose, T., 2001. Modeling the rhizosphere, In R. Pinton, Z. Varanini and P. Nannipieri (eds.) The Rhizosphere. Dekker, New York, pp. 327-372.

De Bruijn, F.J. 1992. Use of repetitive (Repetitive extragenic palindromic and enterobacterial repetitive intergeneric consensus sequences and the polymerase chain reaction to fingerprint the genomes of Rhizobium meliloti isolates and other soil bacteria. Appl. Environ. Microbiol. 58, 2180-2187.

De Weger, L.A., van der Bij, A.J., Dekkers, L.C., Simons, M., Wijffelman, C.A., and Lugtenberg, B.J.J., 1995. Colonization of the rhizosphere of 
crop plants by plant-beneficial pseudomonads. FEMS Microbiol. Ecol. 17 (4), 221-227.

Duineveld B.M. and van Veen, J.A., 1999. The number of bacteria in the rhizosphere during plant development: Relating colonyforming units to different reference units. Biol. Fertil. Soils, 28 (3), 285-291.

Estrada-De-Los-Santos, P., BustillosCristales-Rocio, C.R., and CaballeroMellado-Jesus, M.J., 2001. Burkholderia, a genus rich in plantassociated nitrogen fixers with wide environmental and geographic distribution. Appl. Environ. Microbiol., 67 (6), 2790-2798.

Haider, K., Mosier, A., and Heinmeyer, O., 1985. Phytotron experiments to evaluate the effect of growing plants on denitrification. Soil Sci. Soc. Am. J., 49, 636-641.

Haller, T. and Stolpe, H., 1985. Quantitative estimation of root exudation of maize plants. Plant Soil, 86, 207-216.

Hedlund-Brian, P., Geiselbrecht-Allison, D., Timothy, J.B., and Staley,J.T., 1999. Polyciclic aromatic hydrocarbon degradation by a new marine bacterium, Neptunomonas napthovorans sp. Appl. Environ. Microbiol., 65, 251-259.

Kennedy, A.C., 1999. Bacterial diversity in agroecosystems. Agric. Ecosys. Environ., 74, 65-76.

Kraffczyk, I., Trolldenier, G., and Beringer,H., 1984. Soluble root exudates of maize: influence of potassium supply and rhizosphere microorganisms. Soil Biol. Biochem., 16, 315-322.

Liljeroth, E., Burgers, S.L., and van Veen, J.A., 1991. Changes in bacterial populations along roots of wheat
(Triticum aestivum L.) seedlings. Biol. Fertil. Soils, 10, 276-280.

Lynch, J.M., 1994. The rhizosphere-form and function. Appl. Soil Ecol., 1, 193198.

Neumann, G. and Römheld, V., 2001. The release of root exudates as affected by the plant's physiological status In R. Pinton, Z. Varanini and P. Nannipieri (eds.). The Rhizosphere. Dekker, New York, pp. 41-94.

Peix, A., Mateos, P.F., Rodriguez-Barrueco, C., Martinez-Molina, E., Velazquez, E. 2001. Growth promotion of common bean (Phaseolus vulgaris L.) by a strain of Burkholderia cepacia under growth chamber conditions. Soil Biol. Biochem., 33, 1927-1935.

Picard, C., Di-Cello, F., Ventura, M., Fani, R., and Guckert, A., 2000. Frequency and biodiversity of 2,4diacetylphloroglucinol-producing bacteria isolated from the maize rhizosphere at different stages of plant growth. Appl. Environ. Microbiol., 66 (3), 948-955.

Pikovskaya, R.I., 1948. Mobilization of phosphorus in soil in connection with vital activity by some microbial species. Mikrobiologia, 17, 362-370.

Piña, R.G. and Cervantes, C., 1996. Microbial interactions with aluminium. BioMetals, 9, 311-316.

Rodríguez, H., Gonzales, T., and Selman, G., 2000. Expression of a mineral phosphate solubilizing gene from Erwinia herbicola in two rhizobacterial strains. J. Biotechnol., 84, 155-161.

Versalovic, J., Schneider, M., De Bruijn, F.J., and Lupski, J.R., 1994. Genomic fingerprinting of bacteria using repetitive sequence-based polymerase chain reaction. Methods Mol. Cell. Biol., 5 (1), 25-40. 